ReVISTA de BIOLOGía TROPICAL

\title{
Histochemical differences along the intestine of Corydoras paleatus (Siluriformes: Callichthyidae)
}

\author{
Silvia E. Plaul ${ }^{1 *}$, Claudio G. Barbeito ${ }^{1} \&$ Alcira O. Díaz ${ }^{2}$
}

1. Laboratorio de Histología y Embriología Descriptiva, Experimental y Comparada, Facultad de Ciencias Veterinarias, UNLP. La Plata, Buenos Aires, Argentina; splaul@fcnym.unlp.edu.ar, barbeito@fcv.unlp.edu.ar

2. Laboratorio de Histología e Histoquímica. Departamento de Biología. Instituto de Investigaciones Marinas y Costeras (IIMyC), Facultad de Ciencias Exactas y Naturales, CONICET. UNdMP. Mar del Plata, Buenos Aires, Argentina; adiaz@bart.mdp.edu.ar

* Correspondence

Received 27-II-2015. Corrected 20-VII-2015. Accepted 25-VIII-2015.

\begin{abstract}
The Neotropical catfish Corydoras paleatus is a facultative air-breather and the caudal half of the intestine is involved in gas exchange. In South America, air-breathing fishes are found in tropical or sub-tropical freshwaters where the probability of hypoxia is high. The aim of this study was to characterize by traditional histochemical and lectinhistochemical methods the pattern of carbohydrate in the intestinal mucosa. Intestine samples were taken from 25 healthy adult specimens collected in Buenos Aires (Argentina). Samples were fixed by immersion in $10 \%$ buffered formalin and routinely processed and embedded in paraffin wax. Subsequently, these sections were incubated in the biotinylated lectins battery. Labeled Streptavidin-Biotin (LSAB) system was used for detection, diaminobenzidine as chromogen and haematoxylin as a contrast. To locate and distinguish glycoconjugates (GCs) of the globet cells, we used the following histochemical methods: PAS; PAS*S; KOH/ $\mathrm{PA} * \mathrm{~S} ; \mathrm{PA} / \mathrm{Bh} / \mathrm{KOH} / \mathrm{PAS} ; \mathrm{KOH} / \mathrm{PA}$ */Bh/PAS; Alcian Blue and Toluidine Blue at different pHs. Microscopically, the general structure of vertebrate intestine was observed and showed all the cell types characteristic of the intestinal epithelium. The cranial sector of catfish intestine is a site of digestion and absorption and its structure is similar to other fish groups. In contrast, enterocytes of the caudal portion are low cuboidal cells; and between these, globet cells and capillaries are observed, these latter may reach the mucosal lumen. Underlying the epithelium, observed a well-developed lamina propria-submucosa made of connective tissue; this layer was highly vascularized and did not exhibit glands. According to histochemistry, the diverse GCs elaborated and secreted in the intestine are associated with specific functions in relation to their physiological significance, with special reference to their role in lubrication, buffering effect and prevention of proteolytic damage to the epithelium together with other biological processes, such as osmoregulation and ion exchange. The lectinhistochemical analysis of the intestinal mucosa reveals the presence of terminal residues of glucose, mannose and galactose. In conclusion, this study has shown that GCs synthesized in the intestine of C. paleatus exhibit a high level of histochemical complexity and that the lectin binding pattern of the intestinal mucosa is characteristic of each species and the variations are related with the multiple functions performed by the mucus in the digestive tract. The information generated here may be a relevant biological tool for comparing and analyzing the possible glycosidic changes in the intestinal mucus under different conditions, such as changes in diet or different pathological stages. Rev. Biol. Trop. 64 (1): 327-340. Epub 2016 March 01.
\end{abstract}

Key words: Corydoras paleatus, glycoconjugates, histochemistry, intestine, lectinhistochemistry, goblet cells.

Teleosts have developed a great variety of mechanisms to inhabit all existing aquatic environments and feed both on animals and plants (Wilson \& Castro, 2011). Despite the differences among species resulting from these ecological variations, the general morphological pattern of teleost's intestine corresponds with that of other vertebrates, which is divided into regions that cannot always be distinguished macroscopically (Cao \& Wang, 2009; 
Leknes, 2009; Cao, Wang, \& Song, 2011). Microscopically, in the great majority of fish species, intestinal wall is described by three (Çinar \& Şenol, 2006) or four tunics (Olaya et al., 2007; Wilson \& Castro, 2011; Xiong et al., 2011), depending on whether the tunica submucosa is considered together with the tunica mucosa or not.

Mucus, the product of the hydratation of mucins, is a common feature in the tunica mucosa of vertebrates; it is secreted by the goblet cells or mucous cells (MC) (Yashpal, Kumari, Mittal, \& Mittal, 2007; Díaz, García, Figueroa, \& Goldemberg, 2008a; Díaz, García \& Goldemberg, 2008b; Tano de la Hoz, Flamini, \& Díaz, 2012). These cells secrete a variety of mucins that contribute to the generation of a gelatinous layer, to protect and lubricate the intestinal surface to facilitate the transport of food and reduce the epithelial mechanical stress. Recent studies of molecular biology indicate that $\mathrm{MC}$ also participates in signaling pathways leading to a coordinated response for proliferation, differentiation, apoptosis and cell adhesion (Pérez-Sánchez et al., 2013). Several authors have studied the mucins distribution and their role in the process of digestion, in the local immune responses and antimicrobial action for defense against a wide range of injuries (Carraway, Ramsauer, Haq, \& Carraway, 2003; Sasaki, Ikeda, \& Nakanuma, 2007). The identification of the different types of GCs present in tissue sections can be made using conventional histochemical techniques (Díaz et al., 2008b).

Air-breathing fishes are commonly found in tropical or sub-tropical fresh waters that are ambient ion-poor and prone to hypoxia and hypercarbia (Shartau \& Brauner, 2014). The Neotropical catfish Corydoras paleatus Jenyns 1842 is a facultative air-breather and the caudal half of the intestine is involved in gas exchange (Podkowa \& Goiakowska-Witalinska, 2002). To date, despite the commercial importance of this species like ornamental fish, there have been few studies on the digestive tract of C. paleatus.
The aim of this study was to characterize the carbohydrate pattern composition of mucins secreted by cells of the tunica mucosa in different regions of the intestine of C. paleatus. Furthermore, lectinhistochemical (LHC) technique is used to locate, identify and differentiate variations in the saccharide residues present in the glycoconjugates (GCs) with the aim to discriminate different cell populations (Barbeito, Ortega, Matiller, Gimeno, \& Salvetti, 2013).

\section{MATERIALS AND METHODS}

Animals: Twenty-five healthy adult specimens ( 15 females and 10 males) of $C$. paleatus (LS: $62.22 \pm 1.84 \mathrm{~mm}$ for females and 51.70 $\pm 1.54 \mathrm{~mm}$ for males) were used. The field work was carried out in streams situated in $\mathrm{La}$ Plata, Buenos Aires, Argentina. The handling, collection and slaughter process of all individuals followed the guidelines of the American Fisheries Society (A.F.S., 2004). Fish were transported alive in plastic bags, and were kept in an aquarium at $22^{\circ} \mathrm{C}$ and $\mathrm{pH} 7.0$ (Gómez, 1996) for a minimum of three weeks, they were fed at sunset with food for bottom fish (Tetra min tropical tablet, Germany). The animals were slaughtered by an anesthesia overdose using a Eugenol (30 mg/L) (García-Gómez, de la Gándara, \& Raja, 2002).

Sampling: The necropsies were carried out immediately after sacrifice, the digestive tract was rapidly removed and samples were fixed by immersing in $10 \%$ buffered formalin before the dehydration in an ethanol series and xylene, and posteriorly embedded in paraffin. Samples of intestine were longitudinally divided into three parts (cranial, middle and caudal portions) considering the shape, transparency, thickness of the wall and the width of the lumen in transverse sections. The cranial portion or intestine 1 (I1) has a typical tubular form and its wall is opaque; the middle area, which was subdivided into two portions, intestine 2 (I2) and intestine 3 (I3), has a broader lumen and its wall became thinner and more translucent than 
I1; in the caudal portion or intestine 4 (I4), the lumen diameter kept increasing and the wall was even thinner. Histological sections were cut using a sledge microtome, prepared according to standard protocol, and then stained using routine techniques haematoxylin and eosin (H-E) and Masson trichrome staining for morphology (Martoja \& Martoja, 1970).

Traditional histochemistry: Sections of tissue were also subjected to histochemical procedures for GCs identification, as detailed in Table 1. The combined technique AB pH 2.5/ PAS allowed the identification of three groups of goblet cells. With regard to this, was calculated the percentage of goblet cells for each group in the different intestinal portions using the following formula:

$$
\% \text { of globet cells= }
$$

cells number of each group/total number of cells counted.

Lectinhistochemistry: Labeling with biotinylated lectins was used to identify specific sugar residues of GCs (Díaz et al., 2008b). Fifty different specific lectins, purchased at Vector Laboratories, Inc. (Burlingame, CA, USA) were employed (Table 2). Paraffin sections were deparaffinised with xylene and decreasing ethanol series, and incubated in $0.03 \% \mathrm{H}_{2} \mathrm{O}_{2}$ in methanol for $30 \mathrm{~min}$ at room temperature, to inhibit the endogenous peroxidase. Sections then were treated with 0.1 $\%$ bovine serum albumin in PBS for $30 \mathrm{~min}$ and incubated with fifteen Biotinylated lectins for $2 \mathrm{~h}$ at room temperature. After that, sections were washed separately and subsequently treated with an avidin-biotin-peroxidase complex (ABC kit, Vectastain Elite PK 6 200). Diaminobenzidine (DAB) $0.02 \%$ (Biogenex, San Ramón, CA) was used with chromogen. Slides were counterstained with Mayer's haematoxylin. Staining intensity was graded according to a semiquantitative range (-) negative reaction, (1) weak reaction, (2) moderate reaction, (3) strong reaction. Controls for lectin staining included exposure of the specimens to substrates without lectin and incubation of samples using lectins pre-incubated with the corresponding sugar inhibitors.

Micrographs were taken with an Olympus microscope, CX 31 equipped with an Olympus camera U-CMAD3 (Tokyo, Japan).

\section{RESULTS}

Digestive tract of $C$. paleatus had a short oesophagus and a J-shaped stomach localized

TABLE 1

Histochemical procedures for visualizing and identifying GCs in the intestine of C.paleatus

\begin{tabular}{|c|c|c|}
\hline Procedures & Interpretation of staining reactions & References \\
\hline PAS & GPs with oxidizable vicinal diols and/or glycogen & Mc Manus (1948) \\
\hline $\mathrm{KOH} / \mathrm{PA} * / \mathrm{Bh} / \mathrm{PAS}$ & Neutral GPs with oxidizable vicinal diols & Volz et al. (1987) \\
\hline $\mathrm{PA} / \mathrm{Bh} / \mathrm{KOH} / \mathrm{PAS}$ & Sialic acid residues with $O$-acyl substitution at $\mathrm{C} 7, \mathrm{C} 8$ or $\mathrm{C} 9$ and $O$-acyl sugars & Reid et al. (1973) \\
\hline $\mathrm{KOH} / \mathrm{PA} * \mathrm{~S}$ & GPs with sialic acid residues & Culling et al. (1976) \\
\hline PAPS & Sialic acid residues & Reid et al. (1973) \\
\hline $\mathrm{AB} \mathrm{pH} 2.5$ & GPs with carboxyl groups (sialic acid or uronic acid) and/or with $O$-sulphate esters & Lev \& Spicer (1964) \\
\hline $\mathrm{AB} \mathrm{pH} 1.0$ & GPs with $O$-sulphate esters & Lev \& Spicer (1964) \\
\hline $\mathrm{AB} \mathrm{pH} 0.5$ & Very sulphated GPs & Lev \& Spicer (1964) \\
\hline TB pH 5.6 & GPs with $O$-sulphate esters and carboxyl groups & Lison $(1953)$ \\
\hline TB pH 4.2 & GPs with $O$-sulphate esters & Lison $(1953)$ \\
\hline $\mathrm{AB} \mathrm{pH}$ 1.0/PAS & GPs with $O$-sulphate esters /GPs with oxidizable vicinal diols and/or glycogen & Mowry (1963) \\
\hline $\mathrm{AB} \mathrm{pH} 2.5 / \mathrm{PAS}$ & $\begin{array}{l}\text { GPs with carboxyl groups (sialic acid or uronic acid) and/or with } O \text {-sulphate esters / } \\
\text { GPs with oxidizable vicinal diols and/or glycogen }\end{array}$ & Mowry (1963) \\
\hline
\end{tabular}

AB: alcian blue; Bh: borohydride; GCs: glycoconjugates; $\mathrm{KOH}$ : saponification; PA*: selective periodic acid oxidation; PAS: periodic acid Schiff reagent; PA*S: periodic acid-Schiff at low temperature and low $\mathrm{pH}$; TB: toluidine blue. 
TABLE 2

Carbohydrate binding specificity of lectins employed in this study

\begin{tabular}{cll}
\multicolumn{1}{c}{ Lectin } & \multicolumn{1}{c}{ Source } & \multicolumn{1}{c}{ Binding specificity } \\
Group I & & Glc/Man \\
Con-A & Concanavalia ensiformis & $\beta-\mathrm{D}-\mathrm{Man}>\alpha-\mathrm{D}-\mathrm{Glc}$ \\
LCA & Lens culinaris & $\alpha-\mathrm{D}-\mathrm{Man}$ \\
Group II & & GlcNAc \\
WGA & Triticum vulgaris & $\beta-\mathrm{D}-\mathrm{GlcNAc}$; NeuNAc \\
sWGA & Triticum vulgaris & GlcNAc \\
DSA & Datura stramonium & $\beta 1-4 \mathrm{GlcNAc}$; N-acetilgalactosamine \\
LEA & Lycopersicon esculentum & $\beta 1-4 \mathrm{GlcNAc}$ oligomers \\
Group III & & GalNAc/Gal \\
DBA & Dolichos biflorus & $\alpha-\mathrm{D}-\mathrm{GalNAc}$ \\
VVA & Vicia villosa & Terminal GalNAco1-3Gal $>$ GalNAc $\alpha 1-6 \mathrm{Gal}=\mathrm{GalNAc}-\mathrm{serine}$ \\
SBA & Glycine maximus & $\alpha-\mathrm{D}-\mathrm{GalNAc} ; \beta-\mathrm{D}-\mathrm{GalNAc}$ \\
SJA & Sophora japonica & $\mathrm{GalNAc}$ \\
PNA & Arachis hypogaea & $\beta-\mathrm{D}-\mathrm{Gal}(\beta 1-3)>\mathrm{D}-\mathrm{GalNAc}$ \\
RCA-I & Ricinus communis & $\beta-\mathrm{Gal}$ \\
JAC & Arthocarpus integrifolia & $\alpha-\mathrm{Gal}$ \\
BS-I & Bandeiraca simplicifolia-I & $\beta-\mathrm{Gal}$ \\
Group IV & & L-FUC \\
UEA-I & Ulex europaeus-1 & L-Fuc \\
\hline
\end{tabular}

Gal=galactose; GalNAc $=\mathrm{N}$-acetylgalactosamine; Glc $=$ glucose; GlcNAc $=\mathrm{N}$-acetylglucosamine; L-Fuc $=\mathrm{L}$-fucose; Man=mannose; NeuNAc=N-acetyl-neuraminic acid (sialic acid).

behind the liver. Between the stomach and the intestine, there was a layer of thick muscle (the gastrointestinal sphincter). The total longitude of the intestine was of $54.9 \pm 2.01 \mathrm{~mm}$ for females and $45.9 \pm 1.76 \mathrm{~mm}$ for males.

Histological characterization: Microscopically the general four-layered structure of a vertebrate intestine was observed and showed all the cell types characteristic of the intestinal epithelium (Fig. 1). The tunica mucosa of intestine showed a single-layered columnar epithelium (enterocytes) with a well-developed brush border (Fig. 1C). This cellular type became gradually less numerous and smaller towards the caudal portions; the brush border of these cells also decreased in height caudally (Fig. 1D). The goblet cells or mucous cells (MC), which were arranged among the enterocytes, increased in number towards the caudal portion of the intestine. The most important change that was observed in the intestinal epithelium was related with the extraction of atmospheric oxygen in sectors I3 and I4, transforming the intestine into a complementary air-breathing organ. In these sectors, the epithelium was low cubic (Fig. 1D), and interspersed between enterocytes, $\mathrm{MC}$ and capillaries that reach the lumen of the mucosa were observed. Underlying the epithelium, a well-developed lamina propria-submucosa consisting of connective tissue; this layer was observed highly vascularized and did not exhibit glands (Fig. 1B). No muscularis mucosa was detected, but a thin layer of reticular fibers separating the lamina propria of the tunica submucosa was present. The tunica muscularis was composed of two relatively thick layers of smooth muscle (Fig. 1A), among which the myenteric plexus was located. Towards the caudal sector, the outer longitudinal layer became thinner; in the I4 sector, the tunica muscularis was restricted to 

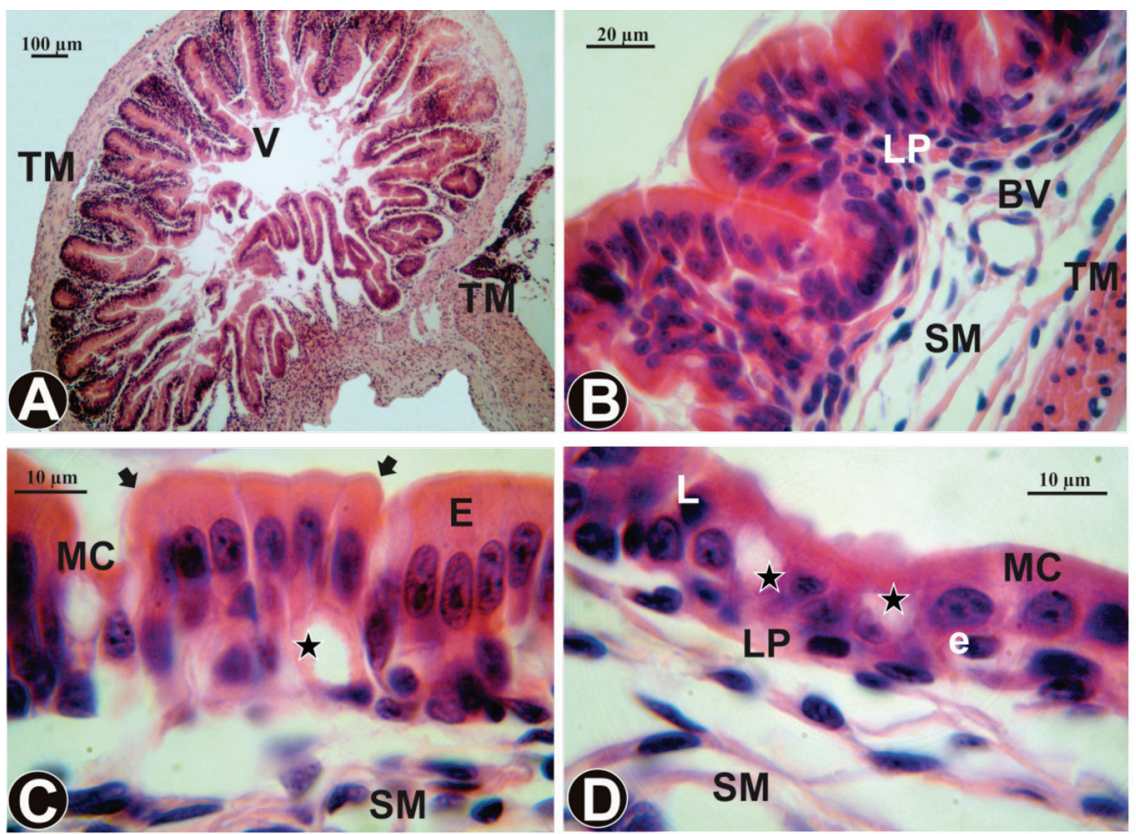

Fig. 1. Histology of the cranial, middle and caudal portion of C. paleatus intestine, H-E. A. Cross-section of I1 portion showing of development of villi and the absence of crypts. B. Portion I2 with shorter and thicker villi than those of the I1 portion, and a great development of lamina propria-submucosa. C. Intestinal mucosa of I3 portion, high-cubic enterocytes with microvillous (arrows) was observed, and blood capillaries (stars) located basally to enterocytes. D. Intestinal wall of I4 portion, blood capillaries (stars) interspersed between the enterocytes were observed. BV: blood vessel, E: enterocytes, e: erythrocyte, L: lymphocyte, LP: lamina propria, MC: goblet cells, SM: tunica submucosa, TM: tunica muscularis, V: villus.

the circular layer. Tunica serosa was composed of a connective tissue and a simple squamous epithelium (mesothelium).

Histochemical characterization: The implementation of different histochemical techniques to demonstrate the presence of GCs in mucous intestinal showed a similar pattern of distribution in the different regions studied. The structures analyzed were glycocalyx and MC. The results are summarized in Table 3.

The combined technique $\mathrm{AB}$ pH 2.5/PAS allowed the identification of three MC types in all intestinal portions (Fig. 2). Due to this reason, $\mathrm{MC}$ populations were called type A (AB/PAS-positive), type B (only PAS-positive) and type $\mathrm{C}$ (only $\mathrm{AB}$-positive). In all sectors there was a predominance of type $\mathrm{A}$, but the intensity of staining varied among the different
TABLE 3

Histochemical reactions of GCs in different portions of the C.paleatus intestine

\begin{tabular}{lcccccccc} 
& \multicolumn{3}{c}{ I1 } & \multicolumn{2}{c}{ I2 } & \multicolumn{2}{c}{ I3 } & \multicolumn{2}{c}{ I4 } \\
& G & MC & G & MC & G & MC & G & MC \\
PAS & 3 & 3 & 3 & 3 & - & 3 & - & 3 \\
KOH/PA*/Bh/PAS & 3 & 3 & - & 3 & - & 3 & - & 3 \\
KOH/PA*S & 2 & 2 & - & 3 & - & 3 & - & 3 \\
PA/Bh/KOH/PAS & $2 / 3$ & $2 / 3$ & 1 & 3 & - & 3 & - & 3 \\
PAPS & 2 & 2 & 2 & 2 & - & $2 / 3$ & - & 3 \\
AB pH 0.5 & - & 1 & - & 1 & - & 1 & - & 1 \\
AB pH 1.0 & 2 & 3 & $2 / 3$ & 3 & - & 3 & - & 3 \\
AB pH 2.5 & $2 / 3$ & 2 & 1 & 2 & - & 2 & - & 2 \\
TB pH 4.2 & - & 2 & - & 2 & - & 2 & - & 2 \\
TB pH 5.6 & - & 2 & - & 2 & - & 2 & - & 2 \\
\hline
\end{tabular}

I1: intestine 1; I2: intestine 2; I3: intestine 3; I4: intestine 4. G: glycocalyx; MC: goblet cells. Staining intensity: negative; 1: weakly positive; 2: moderately positive; 3 : strongly positive. 


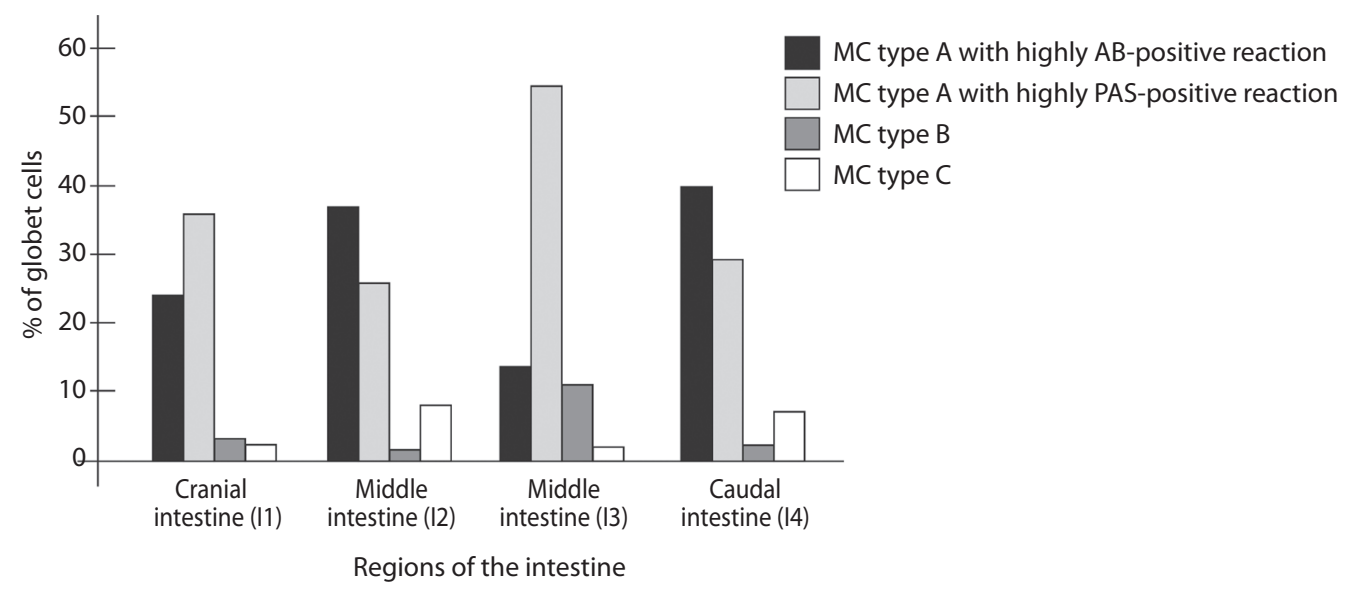

Fig. 2. Percentage of goblet cells (MC) with $\mathrm{AB}$ pH 2.5/PAS staining shows different regions of the C.paleatus intestine.

sectors. Type A cells that were found in I1 and I3 (Fig. 3A, Fig. 3C) showed a highly PASpositive reaction, this confirmed the presence of GCs with oxidizable vicinal diols in a major proportion. However, in I2 and I4 (Fig. 3B, Fig. 3D) the type A cells showed a highly
AB-positive reaction that evidenced an increase of GCs with weak acid sulfated mucins.

Cranial intestine (I1): The glycocalyx showed a moderately to strong positive reaction with the PAS and all its variants (Fig. 4A,
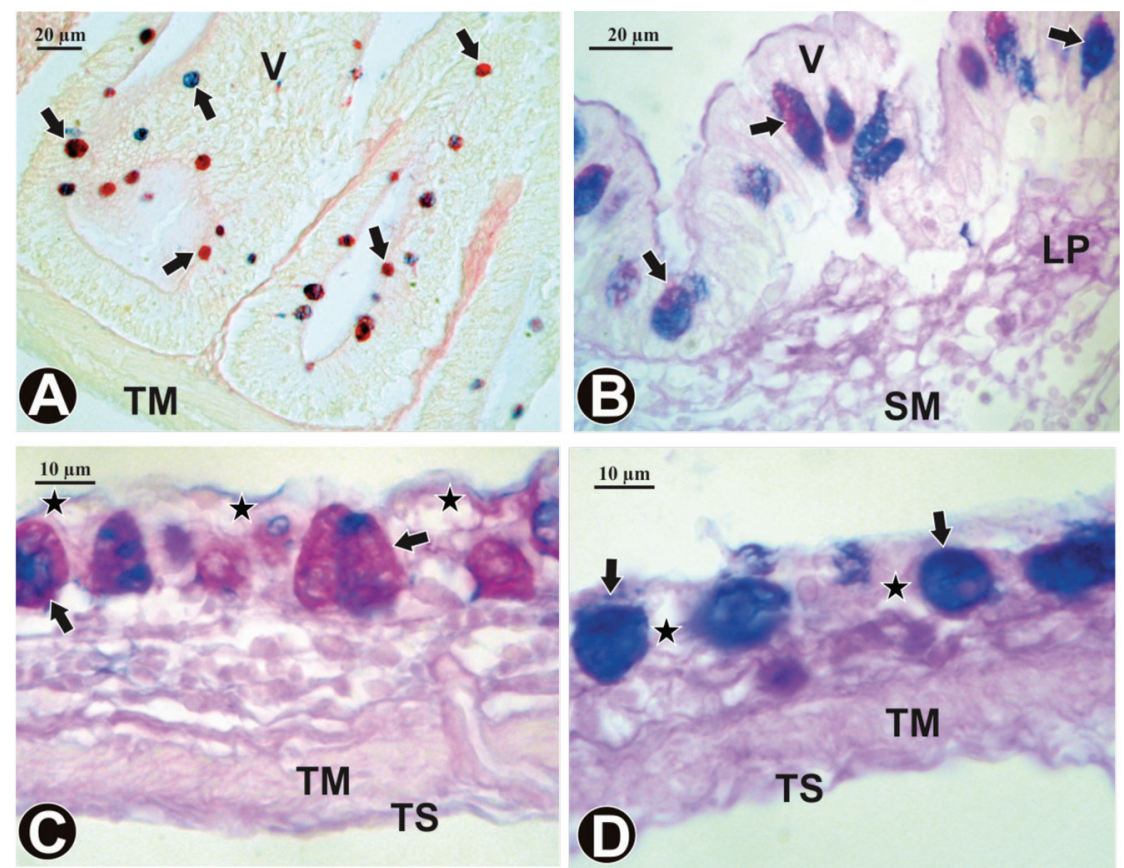

Fig. 3. GC histochemistry of the intestine of $C$. paleatus with a mixed AB pH 2.5/PAS staining. A. Basal surface of the villi of the I1 portion, scarce goblet cells (arrows) AB/PAS-positive reaction. B. Intestinal wall of portion I2, goblet cells of type A (arrows), with a predominance of AB-positive reaction. C. Intestinal wall of portion I3, goblet cells of type A (arrows), with a predominance of PAS-positive reaction. D. Intestinal wall of portion I4, in this sector, the goblet cells are highly AB-positive. $\star$ : blood capillaries, LP: lamina propria, SM: tunica submucosa, TM: tunica muscularis, $\star$ TS: tunica serosa, V: villus. 

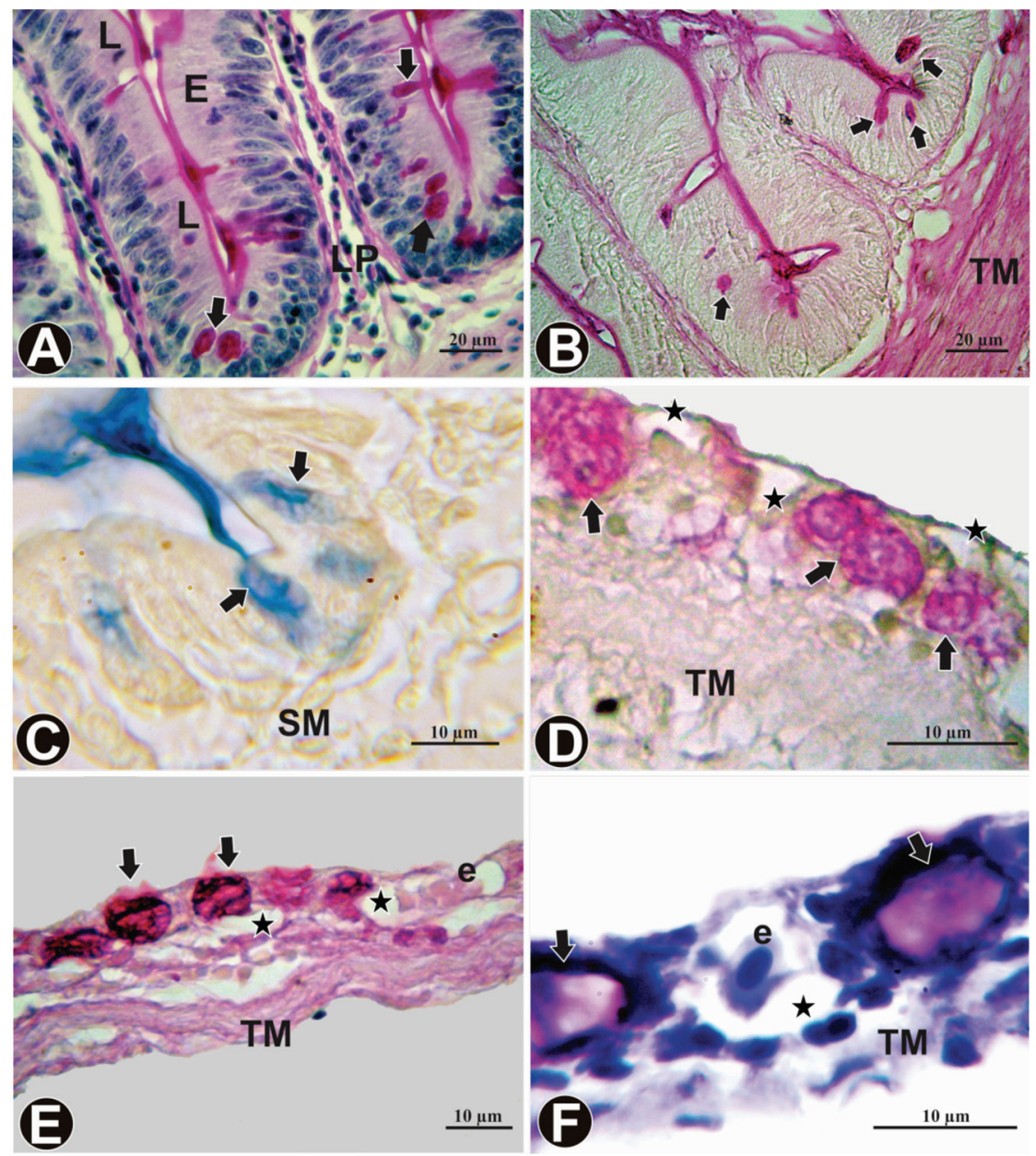

Fig. 4. GC histochemistry of the intestine of C. paleatus. A. Basal portion of the intestinal villi, goblet cells (arrows) intensely PAS-positive. B. Glycocalyx and goblet cells (arrows) PA*/Bh/KOH/PAS-positive. C. Goblet cells (arrows) of I2 portion, was moderately labeled with $\mathrm{AB}$ pH 1.0 technique. D. Intestinal wall of the $\mathrm{I} 3$ portion, abundant goblet cells (arrows) with a rounded shape, note the proximity of the capillaries to the luminal surface (stars), PAPS technique. E. F. Intestinal wall, note the large size of the tunica mucosa in relation to other tunics, and the presence of goblet cells (arrows) and blood capillaries (stars), $\mathrm{KOH} / \mathrm{PA}$ */Bh/PAS and TB pH 5.6 technique respectively. E: enterocytes, e: erythrocyte, L: lymphocyte, LP: lamina propria, SM: tunica submucosa, TM: tunica muscularis.

Fig. 4B). These results revealed the presence of GCs with oxidizable vicinal diols, GCs with sialic acid residues non-substituted or $O$-acyl substituted in $\mathrm{C} 7, \mathrm{C} 8$ or $\mathrm{C} 9$ and $O$-acyl sugars. Besides, the glycocalyx stained weakly with $\mathrm{AB}$ pH 1.0 and moderately with $\mathrm{AB}$ pH 2.5 demonstrating the presence of abundant GCs carboxylated and scarce sulfated. MC reacted strongly with all techniques used, showing the presence of a variety of GCs (Fig. 4A, Fig. 4B). A positive metachromatic reaction with the TB technique at both $\mathrm{pHs}$ allowed the identification of GCs with $O$-sulphate esters and carboxyl groups. This sector reacted positively to the $\mathrm{AB}$ technique, which made possible the identification of weak acid sulfated mucins.

Middle intestine (I2 e I3): All histochemical techniques were positive in the I2 and reactivity gradually diminished towards the I3. Unlike the cranial portion, the glycocalyx showed strong reaction to PAS technique 
but weak to moderate to $\mathrm{PA} * \mathrm{Bh} / \mathrm{KOH} / \mathrm{PAS}$ and PAPS. The AB technique showed a scarce reaction for GCs with weak sialic acid and a moderate to strong presence of sulfated GCs. As in the I1 the MC reacted strongly with all techniques (Fig. 4C, Fig. 4D), except to PAPS techniques, which reactivity was moderate in the I2 to strong towards to the I3.

Caudal intestine (I4): The glycocalyx showed negative reaction with all histochemical techniques. These sector also displayed variation in the presence of GCs, the mucosubstances present in $\mathrm{MC}$ were stained very strongly with PAS and its variants (Fig. 4E), AB at different $\mathrm{pHs}$ and $\mathrm{TB}$ at both $\mathrm{pHs}$ (Fig. 4F).

\section{Lectinhistochemical characterization:}

The application of LHC to detect the presence of GCs in the intestinal mucous, showed a different pattern in each region studied. Glycocalyx and cytoplasm of enterocytes, MC and endothelium were observed in order to establish differences among the physiological regions. No labeling was observed in any of the sectors with DSA and LEA lectins, the enterocytes' cytoplasm showed negative reaction to LCA lectin. The results are summarized in Table 4.

Cranial intestine (I1): Intensively positive with JACALIN, RCA-I, sWGA and SBA was found in the apical cytoplasm of enterocytes (Fig. 5A); this demonstrated the presence of terminal galactose residues. Also the glycocalyx' GCs strongly reacted with Con-A. MC showed positively a great variety of lectins, although only DBA positivity to these cells was identified in all regions, with a labeled which became more intense from cranial to caudal.

Middle intestine (I2 e I3): In the enterocytes the only lectin which increased binding intensity from I2 to I3 was Con-A. The opposite happened with sWGA, JACALIN, WGA, DBA, VVA, SBA, and RCA-I indicating a gradual decrease in $\mathrm{N}$-acetylglucosamine and $\mathrm{N}$-acetylgalactosamine/galactose residues. Glycocalyx behaved differently from I1, in the middle intestine WGA and RCA-I labeled intensely, but its affinity gradually decreased to the caudal sector, showing that the glycocalyx

TABLE 4

Lecting binding in the different portions of the intestine of C. paleatus

\begin{tabular}{lcccccccccccccccc}
\multicolumn{1}{c}{} & \multicolumn{1}{c}{ Enterocytes } & \multicolumn{4}{c}{ Glycocalyx } & \multicolumn{3}{c}{ Goblet cells } & \multicolumn{3}{c}{ Endothelium } \\
& I1 & I2 & I3 & I4 & I1 & I2 & I3 & I4 & I1 & I2 & I3 & I4 & I1 & I2 & I3 & I4 \\
CON A & $2 / 3$ & $1 / 2$ & $2 / 3$ & $2 / 3$ & 3 & 3 & 3 & 3 & - & - & - & - & 3 & 3 & 3 & 3 \\
LCA & - & - & - & - & - & - & 1 & 2 & - & - & - & - & - & - & 1 & 2 \\
WGA & - & 1 & - & - & - & 3 & 2 & $-/ 1$ & 3 & - & - & - & - & - & 1 & $-/ 1$ \\
sWGA & $1 / 2$ & $2 / 3$ & - & - & - & 1 & $1 / 2$ & $1 / 2$ & - & - & - & - & - & - & $1 / 2$ & $1 / 2$ \\
DSA & - & - & - & - & - & - & - & - & - & - & - & - & - & - & - & - \\
LEA & - & - & - & - & - & - & - & - & - & - & - & - & - & - & - & - \\
DBA & 1 & 1 & - & - & 2 & 2 & 3 & 3 & $1 / 2$ & 1 & $1 / 2$ & $2 / 3$ & 2 & 2 & 3 & 3 \\
VVA & $2 / 3$ & 3 & $1 / 2$ & $2 / 3$ & - & - & - & - & - & - & $1 / 2$ & $2 / 3$ & 3 & - & - & - \\
SBA & 2 & 1 & - & - & - & 2 & 2 & 2 & - & - & 3 & $2 / 3$ & - & - & 2 & 2 \\
SJA & - & - & - & - & - & - & 1 & 1 & - & - & - & - & - & - & 1 & 1 \\
PNA & 1 & - & - & - & 2 & - & - & 2 & - & - & - & - & - & - & 1 & 2 \\
RCA-I & $2 / 3$ & 1 & - & 3 & - & 3 & $1 / 2$ & 3 & - & - & - & - & - & 3 & $1 / 2$ & 3 \\
JACALIN & 2 & 2 & - & - & - & - & - & - & 3 & $2 / 3$ & $2 / 3$ & - & - & - & - & - \\
BS-I & - & - & - & - & - & - & - & - & - & - & - & - & - & - & - & - \\
UEA-I & - & - & - & - & - & - & - & 3 & - & - & - & - & - & - & 1 & 3
\end{tabular}

I1: intestine 1; I2: intestine 2; I3: intestine 3; I4: intestine 4. Staining intensity: -: negative; 1: weakly positive; 2: moderately positive; 3 : strongly positive. 

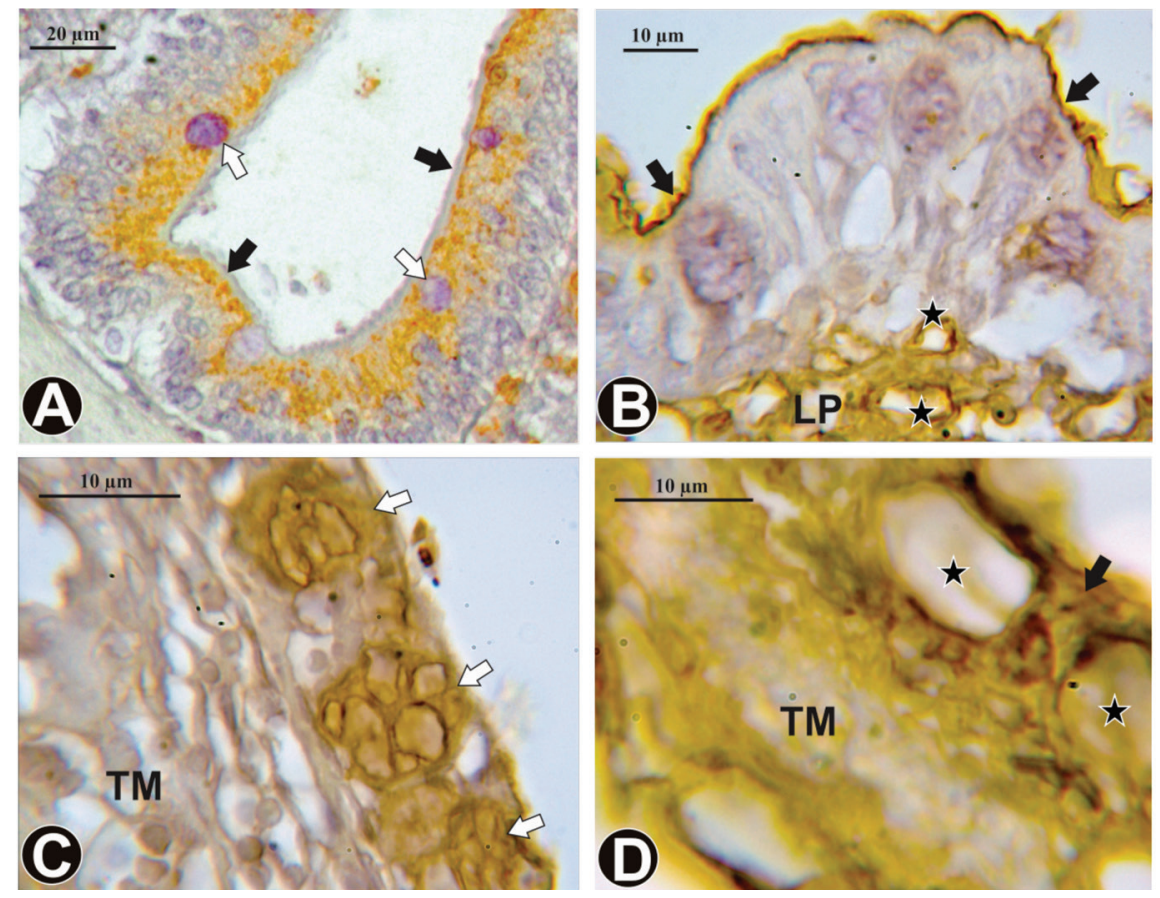

Fig. 5. LHC staining of the intestine of C. paleatus. A. SBA lectin binding is present in the enterocytes apical cytoplasm of portion I1, and absent in glycocalyx (black arrows) and goblet cells (white arrows). B. In portion I2, RCA-I lectin binding shows positivity in glycocalyx (black arrows) and capillaries endothelium (stars) of lamina propria. C. Intestinal wall of portion I3, note the heterogeneous positivity of goblet cells (white arrows) with SBA lectin binding. D. Con-A lectin binding is evident in the enterocytes (arrow) located between two blood capillaries (stars). LP: lamina propria, TM: tunica muscularis.

of I2 (Fig. 5B) is rich in $\mathrm{N}$-acetylglucosamine and galactose, but these residues were gradually lost when reaching the caudal region. $\mathrm{MC}$ were positive with four lectins, DBA, VVA, SBA and JACALIN (Fig. 5C); from these, only the latter remained from moderate to strong labeled in both sectors. The others were increasing their affinity towards the caudal region. All these lectins belong to the group that recognizes $\mathrm{N}$-acetylgalactosamine and galactose. Endothelial cells of the regions I1 and I 2 showed a great similarity.

Caudal intestine (I4): Con-A, RCA-I and VVA bind to GCs in the cytoplasm of enterocytes (Fig. 5D). Lectins that had a positive reaction for the $\mathrm{MC}$ were the same as for $\mathrm{I} 3$ but remained constant in labeling intensity with JACALIN. However DBA and VVA labeled more intensively, while SBA decreased its affinity abruptly. All of them belong to the group of lectins that recognizes $\mathrm{N}$-acetylgalactosamine and galactose. LCA, WGA, sWGA, DBA, SBA and SJA showed a similar binding pattern in endothelial cells of the regions I3 and I4.

\section{DISCUSSION}

The morphology and histology of the gastrointestinal tract has been described for several teleost species. Despite interspecific differences, this system has showed to share basic structural features (Díaz, García, Devincenti, \& Goldemberg, 2003; Díaz et al., 2008a,b; Domeneghini, Arrighi, Radaelli, Bosi, \& Veggetti, 2005; Fishelson, Golani, Russell, Galil, \& Goren, 2011). However, the morphological and functional variations found in $C$. 
paleatus demonstrated specializations in this group of vertebrates, not only in relation to its position in the food chain, but also for their habitat. In $C$. paleatus, histological characteristics of the intestinal mucosa, submucosa, muscular and serosa tunics coincided with other studied teleost (Olaya et al., 2007), with the exception of the I3 and I4 portions. These sectors present modifications in relation to gas exchange such as a very thin wall and the presence of many capillaries located basally, in between, and apically to the epithelial cells. A similar intestinal wall has been observed in teleosts in which the intestine has an accessory respiratory function, like other members of the order Siluriformes (Huebner \& Chee, 1978; Podkowa \& Goiakowska-Witalinska, 2002; Jucá-Chagas \& Boccardo, 2006), and also some members of the family Cobitidae (Jasinski, 1973; Yadav \& Singh, 1980; Park \& Kim, 2001; Gonçalves, Castro, Pereira-Wilson, Coimbra, \& Wilson, 2007).

$\mathrm{HC}$ and LHC patterns of the mucosal layer differ among species and in different regions of the digestive tract (Reid, Volz, Cho, \& Owen, 1988; Grau, Crespo, Sarasquete, \& González de Canales, 1992; Leknes, 2011). In this research, a variety of GCs in the glycocalyx of I1, and a moderated to strong presence of sulfated GCs were observed. This positivity decreased gradually towards the caudal portion of the intestine where it became negative for all techniques in portion I3 and I4. These results confirm the functional differences that these cells possess along the intestine. The glycocalyx, extending in the apical surface of I1 and I2, has a buffer effect on the high acidity from the stomach. Additionally, to protecting the epithelial cells from the action of proteolytic enzymes, the glycocalyx plays a key role in cell-pathogen interactions (Vásquez-Piñeros, Rondón-Barragan, \& Eslava-Mocha, 2012). Also, the glycocalyx and the endothelial cells in $C$. paleatus showed a strong affinity for lectins Con-A and DBA in the whole intestine and UEA-I in the I4 portion. These results demonstrated that glucose/mannose; N-acetilgalactosamine and L-fucose residues would probably have general functions in the intestinal epithelium that do not depend on the sector. Previous studies had also described the role of L-fucose, with an important function in morphogenetic processes of the plasmatic membranes, and increasing the resistance against bacterial populations in the apical border of enterocytes (Bennett, Leblond, \& Haddad, 1974; Vásquez-Piñeros et al., 2012). Enterocytes cytoplasm showed affinities to the four groups of lectins, but only Con-A and VVA lectins bound from moderately to intensively in all sectors of the intestine. The enterocytes of Paralichthys olivaceus (Jung, Ahn, Lee, Go, \& Shin, 2002) and Oncorhynchus mykiss (Marchetti et al., 2006) showed a similar LHC pattern. The LHC method mainly revealed the presence of glucose/mannose and $\mathrm{N}$-acetylgalactosamine residues in the GCs that are produced by the enterocytes and transported to the cell surface along the intestine, and also a weak presence of $\mathrm{N}$-acetylglucosamine and 1.3 $ß \mathrm{~N}$-acetylgalactosamine terminal residues. The $\mathrm{HC}$ and LHC patterns of C. paleatus in I1 and I 2 were similar between them, as well as those of I3 and I4; these could indicate that enterocytes belong to two different cell populations.

The presence of MC is a common feature in the intestinal epithelium of teleosts (Grau et al., 1992; Çinar \& Şenol, 2006; Hernández, Pérez Gianeselli, \& Domitrovic, 2009). In the I1 of $C$. paleatus, the MC were scarce and had a low content of highly sulfated mucins and a high content of weak acid mucins. This result agrees with those obtained previously for teleosts of the orders Perciformes, Cypriniformes, Esociformes, Siluriformes, Beloniformes and Salmoniformes (Reifel \& Travill, 1979; Tibbets, 1997; Podkowa \& Goiakowska-Witalinska, 2002; Marchetti et al., 2006; Hernández et al., 2009). In this catfish, the AB combined techniques allowed the identification of three types of MC. In I1 and I3 the carboxylated groups were predominant, in contrast with the abundance the sulphated groups found in I2 and I4. According to the observations made by Yadav and Singh (1980), Podkowa and Goiakowska-Witalinska (2002) and Çinar and Şenol (2006), the caudal portion of the intestine 
contains acidic glycosaminoglycans with high affinity to water, which would be necessary for the maintenance of body moisture. The presence of different types of MC has already been determined in other groups of fishes (Hung, Groff, Lutes, \& Alkins, 1990). Narasimham and Parvatheswarao (1974) and Domeneghini, Stranini, and Veggetti (1998) have suggested that intestinal mucins possibly play a role in osmoregulation. Recently, Pérez-Sánchez et al. (2013) have shown that MUC18, an intestinal mucin that binds to membranes, plays a crucial role in protection against pathogen agents together with other biological processes such as osmoregulation and ion exchange. In addition, Mittal, Whitear, and Agarwal (1980) and Mittal, Pinky and Mittal (2002) observed that the mucus has a remarkable power to precipitate the mud in suspension, keeping the epithelium clean for respiration. Even though these studies were done in skin and opercule, this function could be applied to the intestine of $C$. paleatus since it is a benthic fish that incorporates suspended matter together with water, making it difficult to breathe at the intestinal level.

In conclusion, this study has shown that GCs produced along the intestine of C. paleatus exhibit a high complexity degree associated with the multiple functions performed by the mucus in the digestive tract. Furthermore we found distinctive features of the mucosa in relation to gas exchange such as a very thin wall, presence of many capillaries interspersed between enterocytes in direct contact with the lumen and a decreased of the GCs in the glycocalyx that relate more with their respiratory function than with digestive function. The information generated here may be a relevant biological tool for comparing and analyzing the possible glycosidic changes in the intestinal mucus under different conditions, such as changes in diet or different pathological stages.

\section{ACKNOWLEDGMENTS}

We would like to thank Mabel García and Rubén Mario for this technical work. We are grateful to Jimena Barbeito Andrés and Federico Lozano for reading the MS.

\section{RESUMEN}

Diferencias histoquímicas a lo largo del intestino de Corydoras paleatus (Siluriformes: Callichthyidae). El pez neotropical Corydoras paleatus, de respiración aérea de tipo facultativa, utiliza el sector caudal del intestino para el intercambio gaseoso. En América del Sur, los peces con respiración aérea se encuentran en las aguas dulceacuícolas tropicales y subtropicales, donde la probabilidad de hipoxia es alta. El objetivo de este trabajo fue caracterizar mediante técnicas histoquímicas tradicionales y de lectinhistoquímica el patrón de carbohidratos de la mucosa intestinal. Para ello se utilizaron muestras de intestino de 25 ejemplares sanos adultos recolectados en la provincia de Buenos Aires (Argentina). Las muestras fueron fijadas en formol amortiguado al $10 \%$ y se procesaron para su inclusión en parafina. Posteriormente, los cortes fueron incubados con una batería de lectinas biotiniladas. Se utilizó el sistema de marcado con estreptavidina-biotina (LSAB) para su detección, diaminobencidina como cromógeno y hematoxilina como colorante de contraste. Para localizar y diferenciar los glicoconjugados (GCs) de las células caliciformes, se utilizaron las siguientes técnicas histoquímicas: PAS, PAS*S, PAPS, KOH/PA*S, PA/Bh/KOH/PAS, KOH/PA*/ Bh/PAS, Azul Alcian y Azul de Toluidina a diferentes $\mathrm{pHs}$. Microscópicamente, se observa la estructura general del intestino de los vertebrados y el epitelio intestinal presenta todos los tipos celulares característicos de esta región. El sector craneal del intestino de este teleósteo, es el sitio de digestión y absorción, y posee una estructura similar a la de otros grupos de peces. En cambio, los enterocitos de la porción caudal, son células cúbicas bajas, entre ellos se observan células caliciformes y capilares sanguíneas que llegan hasta el lumen de la mucosa. Por fuera del epitelio, se observa una lámina propia-submucosa muy desarrollada compuesta por tejido conectivo, altamente vascularizada que no presenta glándulas. De acuerdo con las técnicas histoquímicas, los diversos GCs elaborados y secretados por la mucosa intestinal se encuentran asociados con funciones específicas de importancia fisiológica, como su rol en la lubricación, su efecto amortiguador y la prevención de daños proteolíticos del epitelio junto con otros procesos biológicos, tales como la osmorregulación y el intercambio iónico. El análisis lectinhistoquímico de la mucosa intestinal revela la presencia de residuos terminales de glucosa, manosa y galactosa. En conclusión, en este estudio se demuestra que los GCs sintetizados en el intestino de C. paleatus muestran un alto nivel de complejidad histoquímica y que el patrón de unión de lectina de la mucosa intestinal es característico para cada especie y las variaciones se hallan relacionadas con las múltiples funciones realizadas por el mucus en el tracto digestivo. La información brindada en este trabajo es una herramienta de 
relevancia biológica para comparar y analizar los posibles cambios glicosídicos del mucus intestinal bajo diferentes condiciones como los cambios en la dieta o diferentes estados patológicos.

Palabras clave: Corydoras paleatus, glicoconjugados, histoquímica, intestino, lectinhistoquímica, células caliciformes.

\section{REFERENCES}

A. F. S. (2004). Guidelines for the Use of Fishes in Research. Bethesda, MD: American Fisheries Society.

Barbeito, C. G., Ortega, H. H., Matiller, V., Gimeno, E. J., \& Salvetti, N. R. (2013). Lectin-binding pattern in ovarian structures of rats with experimental polycystic ovarian syndrome. Reproduction in Domestic Animals, 48, 850-857.

Bennett, G., Leblond, C. P., \& Haddad, A. (1974). Migration of glycoproteins from the Golgi apparatus to the surface of various cell types as shown by radioautography after labeled fucose injection into rats. Journal of Cell Biology, 60, 258-284.

Cao, X. J., \& Wang, W. M. (2009). Histology and mucin histochemistry of the digestive tract of yellow catfish, Pelteobagrus fulvidraco. Anatomia, Histologia, Embryologia, 38, 254-261.

Cao, X. J., Wang, W. M., \& Song, F. (2011). Anatomical and histological characteristics of the intestine of the topmouth culter (Culter alburnus). Anatomia, Histologia, Embryologia, 40, 292-298.

Carraway, K. L., Ramsauer, V. P., Haq, B., \& Carraway, C. A. C. (2003). Cell signaling through membrane mucins. BioEssays, 25, 66-71.

Çinar, K., \& Şenol, N. (2006). Histological and histochemical characterization of the mucosa of the digestive tract in flower fish (Pseudophoxinus antalyae). Anatomia, Histologia, Embryologia, 35, 147-151.

Culling, C. F. A., Reid, P. E., \& Dunn, W. L. (1976). A new histochemical method for the identification and visualization of both side-chain acylated and nonacylated sialic acids. Journal of Histochemistry \& Cytochemistry, 24, 1225-1230.

Díaz, A. O., García, A. M., Devincenti, C. V., \& Goldemberg, A. L. (2003). Morphological and histochemical characterization of the mucosa of the digestive tract in Engraulis anchoita (Hubbs and Marini, 1935). Anatomia, Histologia, Embryologia, 32, 341-346.

Díaz, A. O., García, A. M., Figueroa, D. E., \& Goldemberg, A. L. (2008a). The mucosa of the digestive tract in Micropogonias furnieri: A light and electron microscope approach. Anatomia, Histologia, Embryologia, $37,251-256$
Díaz, A. O., García, A. M., \& Goldemberg, A. L. (2008b). Glycoconjugates in the mucosa of the digestive tract of Cynoscion guatucupa: A histochemical study. Acta Histochemica, 110, 76-85.

Domeneghini, C., Stranini, R. P., \& Veggetti, A. (1998). Gut glycoconjugates in Sparus aurata L. (Pisces, Teleostei), a comparative histochemical study in larval and adult ages. Histology \& Histopathology, 13, 359-372.

Domeneghini, C., Arrighi, S., Radaelli, G., Bosi, G., \& Veggetti, A. (2005). Histochemical analysis of glycoconjugates secretion in the alimentary canal of Anguilla anguilla L. Acta Histochemica, 106, 477-487.

Fishelson, L., Golani, D., Russell, B., Galil, B., \& Goren, M. (2011). Comparative morphology and cytology of the alimentary tract in lizard fishes (Teleostei, Aulopiformes, Synodontidae). Acta Zoologica (Stockholm), 93, 308-318.

García-Gómez, A., de la Gándara, F., \& Raja, T. (2002). Utilización del aceite de clavo, Syzygium aromaticum L. (Merr. \& Perry), como anestésico eficaz y económico para labores rutinarias de manipulación de peces marinos cultivados. Boletín Instituto Español de Oceanografia, 18, 21-23.

Gómez, S. E. (1996). Resitenza alla temperatura e alla salinità in pescidella provincia di Buenos Aires (Argentina), con implicazioni zoogeografiche. In Distribuzione della fauna ittica italiana. Atti Congressuali IV. Convegno Nazionale A.I.I.A. Riva del Garda, Italia.

Gonçalves, A. F., Castro, L. F. C., Pereira-Wilson, C., Coimbra, J., \& Wilson, J. M. (2007). Is there a compromise between nutrient uptake and gas exchange in the gut of Misgurnus anguillicaudatus, an intestinal air-breathing fish? Comparative Biochemistry and Physiology, Part D2, 345-355.

Grau, A., Crespo, S., Sarasquete, M. C., \& González de Canales, M. L. (1992). The digestive tract of the amberjack Seriola dumerili, Risso: a light and scanning electron microscope study. Journal of Fish Biology, 41, 287-303.

Hernández, D. R., Pérez Gianeselli, M., \& Domitrovic, H. A. (2009). Morphology, histology and histochemistry of the digestive system of South American catfish (Rhamdia quelen). International Journal of Morphology, 27, 105-111.

Huebner, E., \& Chee, G. (1978). Histological and ultrastructural specialization of the digestive tract of the intestinal air breather Hoplosternum thoracatum (Teleost). Journal of Morphology, 157, 301-328.

Hung, S. S. O., Groff, J. M., Lutes, P. B., \& Alkins, F. K. F. (1990). Hepatic and intestinal histology of juvenile white sturgeon fed different carbohydrates. Aquaculture, 87, 349-360. 
Jasinski, A. (1973). Air-blood barrier in the respiratory intestine of the pond-loach, Misgurnus fossilis L. Acta Anatomica, 86, 376-393.

Jucá-Chagas, R., \& Boccardo L. (2006). The air-breathing cycle of Hoplosternum littorale (Hancock, 1828) (Siluriformes: Callichthyidae). Neotropical Ichthyology, 4, 371-373.

Jung, K. S., Ahn, M. J., Lee, Y. D., Go, G. M., \& Shin, T. K. (2002). Histochemistry of six lectins in the tissues of the flat fish Paralichthys olivaceus. Journal of Veterinary Science, 3, 293-301.

Leknes, I. L. (2009). Histochemical study on the intestine goblet cells in cichlid and poecilid species (Teleostei). Tissue Cell, 42, 61-64.

Leknes, I. L. (2011). Histochemical studies on mucin-rich cells in the digestive tract of a teleost, the Buenos Aires tetra (Hyphessobrycon anisitsi). Acta Histochemica, 113, 353-357.

Lev, R., \& Spicer, S. S. (1964). Specific staining of sulphate groups with alcian blue at low $\mathrm{pH}$. Journal of Histochemistry \& Cytochemistry, 12, 309.

Lison, L. (Ed.). (1953). Histochimie et cytochimie animales. In Principes et méthodes (pp. 1-607). Paris: Gauthier-Villars.

Marchetti, I., Capacchietti, M., Sabbieti, M. G., Accili, D., Materazzi, G., \& Menghi, G. (2006). Histology and carbohydrate histochemistry of the alimentary canal in the rainbow trout Oncorhynchus mykiss. Journal of Fish Biology, 68, 1808-1821.

Martoja, R., \& Martoja-Pierson, M. (1970). Técnicas de histología animal. Editorial Toray-Masson S.A.: Barcelona.

Mc Manus, J. F. A. (1948). Histological and histochemical uses of periodic acid. Stain Technology, 23, 99-108

Mittal, A. K., Whitear, M., \& Agarwal, S. K. (1980). Fine structure and histochemistry of the epidermis of the fish, Monopterus cuchia. Journal of Zoology, 191, 107-125.

Mittal, J., Pinky, S., \& Mittal, A. K. (2002). Characterisation of glycoproteins in the secretory cells in the operculum of an Indian hill stream fish Garra lamta (Hamilton) (Cyprinidae, Cypriniformes). Fish Physiology and Biochemistry, 26, 275-288.

Mowry, R. W. (1963). The special value of methods that colour both acidic and vicinal hydroxyl groups in the histochemical study of mucins with revised directions for the colloidal iron stain, the use of Alcian blue $8 \mathrm{GX}$, and their combination with the periodic acidSchiff reaction. Annals of the New York Academy of Sciences, 106, 402-423.

Narasimham, C., \& Parvatheswarao, V. (1974). Adaptation to osmotic stress in a freshwater euryhyaline teleost Tilapia mossambica. X. Role of mucopolysaccharides. Acta Histochemica, 51, 37-49.
Olaya, C. M., Ovalle, C. H., Gomez, E., Rodriguez, D., Caldas, M. L., \& Hurtado H. (2007). Histología y morfometría del sistema digestivo del Silurido bagre tigrito (Pimelodus pictus). Revista de la Facultad de Medicina Veterinaria y de Zootecnia, 54, 311-323.

Park, J. Y., \& Kim, I. S. (2001). Histology and mucin histochemistry of the gastrointestinal tract of mud loach, in relation to respiration. Journal of Fish Biology, $58,861-872$.

Pérez-Sánchez, J., Estensoro, I., Redondo, M. J., CalduchGiner, J. A., Kaushik, S., \& Sitjà-Bobadilla, A. (2013). Mucins as diagnostic and prognostic biomarkers in a fish-parasite model: Transcriptional and functional analysis. PLoS ONE 8, e65457.

Podkowa, D., \& Goiakowska-Witalinska, L. (2002). Adaptations to the air breathing in the posterior intestine of the catfish (Corydoras aeneus). The histological and ultrastructural study. Folia Biologica (Kraków), 50, 69-82.

Reid, P. E., Culling, C. F. A., \& Dunn, W. L. (1973). Saponification induced increase in the periodic acid Schiff reaction in the gastrointestinal tract. Mechanism and distribution of the reactive substance. Journal of Histochemistry \& Cytochemistry, 21, 473-483.

Reid, P. E., Volz, D., Cho, K. Y., \& Owen, D. A. (1988). A new method for the histochemical demonstration of $\mathrm{O}$-acyl sugar in human colonic epithelial glycoproteins. The Histochemical Journal, 20, 510-518.

Reifel, C. W., \& Travill, A. A. (1979). Structure and carbohydrate histochemistry of the intestine in ten teleostean species. Journal of Morphology, 162, 343-360.

Sasaki, M., Ikeda, H., \& Nakanuma, Y. (2007). Expression profiles of MUC mucins and trefoil factor family (TFF) peptides in the intrahepatic biliary system: Physiological distribution and pathological significance. Progress in Histochemistry and Cytochemistry, 42, 61-110.

Shartau, R. B., \& Brauner, C. J. (2014). Acid-base and ion balance in fishes with bimodal respiration. Journal of Fish Biology, 84, 682-704.

Tano de la Hoz, M. F., Flamini, M. A., \& Díaz, A. O. (2012). Histological and histochemical study of the duodenum of the plains viscacha (Lagostomus maximus) at different stages of its ontogenetic development. Acta Zoologica (Stockholm), 95, 21-31.

Tibbets, I. R. (1997). The distribution and function of mucous cells and their secretions in the alimentary tract of Arrhamphus sclerolepis Krefftii. Journal of Fish Biology, 50, 809-820.

Vásquez-Piñeros, M. A., Rondón-Barragan, I. S., \& Eslava-Mocha, P. R. (2012). Inmunoestimulantes en teleósteos: Probióticos, ß-glucanos y LPS. Orinoquia, $16,46-62$. 
Volz, D., Reid, P. E., Park, C. M., Owen, D. A., \& Dum, W. L. (1987). A new histochemical method for the selective periodate oxidation of total tissue sialic acids. Histochemical Journal, 19, 311-318.

Wilson, J. M., \& Castro, L. F. C. (2011). Morphological diversity of the gastrointestinal tract in fishes. In M. Grosell, A. P. Farrell, \& C. J. Brauner (Eds.), The Multifunctional Gut of Fish. Fish Physiology (pp. 136-164). Amsterdam: Academic Press.

Xiong, D., Zhang, L., Yu, H., Xie, C., Kong, Y., Zeng, Y., Huo, B., \& Liu, Z. (2011). A study of morphology and histology of the alimentary tract of Glyptosternum maculatum (Sisoridae, Siluriformes). Acta Zoologica (Stockholm), 92, 161-169.

Yadav, A. N., \& Singh, B. R. (1980). The gut of an intestinal air breathing fish, Lepidocephalus guntea (Ham). Archives of Biology (Bruxelles), 91, 413-422.

Yashpal, M., Kumari, U., Mittal, S., \& Mittal, A. K. (2007). Histochemical characterization of glycoproteins in the buccal epithelium of a catfish Rita rita. Acta Histochemica, 109, 285-303. 